\title{
THE EFFECT OF GALLERY WALK AND MOTIVATION TOWARD STUDENTS' READING COMPREHENSION OF NARRATIVE TEXT AT THE EIGHTH GRADE OF SMP N 2 SAWAHLUNTO
}

\author{
Deni Abdillah. M \\ Universitas Mohammad Natsir Yarsi Bukittinggi \\ deniabdillahm86@gmail.com
}

\begin{abstract}
In learning reading, teaching strategy and motivation have effect on the students' reading comprehension. Gallery walk was used as the variation from reading learning strategies. The goal of this research is to find out the effect of gallery walk and motivation toward students' reading comprehension of narrative text (fable). This research was classified into quasi experimental research. The population of this research was the Eighth-grade students of SMPN 2 Sawahlunto. The technique that was used in selecting the sample was cluster random sampling. The sample of this research was VIII A as the experimental class and VIII $C$ as the control class. The instruments which used in this research were reading comprehension test and questionnaire. The hypotheses were analyzed by using $t$ test and Two Ways ANOVA. The finding shows that (1) Gallery walk strategy gives better effect on students reading comprehension compared to small group discussion. (2) Students' with high motivation and taught by using gallery walk strategy have better reading comprehension compared to small group discussion. (3) Students' with low motivation and taught by using gallery walk does not have better reading comprehension compared to small group discussion. (4) There is no interaction between motivation and students' reading comprehension.
\end{abstract}

Key Words: Gallery Walk, Motivation, Reading Comprehension

\begin{abstract}
Abstrak
Dalam pembelajaran membaca, strategi pembelajaran dan motivasi sangat mempengaruhi pemahaman membaca siswa. Gallery walk diaplikasikan sebagai salah satu variasi dalam strategi pembelajaran membaca. Tujuan penelitian ini adalah untuk mengetahui pengaruh gallery walk dan motivasi terhadap pemahaman membaca siswa di dalam teks narrative (fable). Jenis penelitian ini adalah quasi experimental. Populasi penelitian ini adalah siswa kela VIII SMPN 2 Sawahlunto. Teknik yang digunakan dalam pengambilan sampel adalah cluster random sampling. Sampel penelitian adalah kelas VIIIA sebagai kelas eksperimen dan VIII C sebagai kelas control. Instrumen yang digunakan dalam penelitian ini adalah tes pemahaman membaca dan kuisioner. Hipotesis dianalisa menggunakan T-test dan ANOVA 2 Arah. Hasil penelitian menunjukkan bahwa (1) Gallery walk memberikan dampak yang lebih baik terhadap pemahaman siswa dalam membaca dibandingkan dengan small group discussion. (2) Siswa dengan motivasi yang tinggi diajar menggunakan gallery walk memiliki pemahaman membaca yang lebih baik dibandingkan dengan small group discussion. (3) Siswa dengan motivasi yang rendah dan diajar menggunakan gallery walk tidak memiliki pemahaman yang lebih baik dibandingkan dengan small group discussion. (4) Tidak ada hubungan antara motivasi dan pemahaman membaca siswa.
\end{abstract}

Kata Kunci: Gallery Walk, Motivasi, Membaca 


\section{INTRODUCTION}

In reading class, most of the reading activities focuses on reading for comprehension. The reason is that the students' skills in comprehending the text lead them to expand their knowledge, even to enlarge new information. In junior high school, the students' reading skill is crucial. Reading is one of language skills which should be expanded in teaching-learning process. Among the four skills, reading takes the most portions in semester test and National Examination. It means that reading is the main core tested. Furthermore, reading comprehension is generally used to assess students' triumph in English. When they do the examination, they will find with many kinds of text types. If students do not have good reading comprehension skill, they probably fail to do the examination. In purpose to ensure that, it is expected that students are good readers who are able to comprehend a text effectively and efficiently.

Based on the explanation above, it can be said that the ability or skill of comprehending a message or content in the text is the main goal of reading in the language instruction. As Schramm (2008:231), also states that "reading comprehension is an active process to construct the meaning and the understanding about the text". It can be seen from the fact that students' reading comprehension is still far from what is being expected.

The survey conducted by organization for Economic Cooperation and Development's Program for International Student Assessment 2012 (PISA) shows that Indonesia ranks second from the bottom in an international education survey conducted to assess students' skill in reading.

This also happens to be the case found at the eighth grade of SMPN 2 Sawahlunto, where most students still face difficulties dealing with reading texts written in English. With regard to the preliminary observation, the unsatisfactory results of the students' reading comprehension were caused by several following factors. First, students have low motivation in reading. It can be seen from students' respond (feedback) in the classroom only a few of them participated and most of them were passive. The students who could not follow and understand the lesson well would feel bored and they got less at the end of the class.

Second, most of students think reading was difficult. It is because they did not know the meaning of the key words in reading. As a result, they could not identify making inferences, finding the meaning of words and understand the text structure. Third, the teacher only uses small group discussion in every meeting. Only few students were active. It causes teaching and learning become ineffective. The teacher cannot handle the students who were not active in groups which makes the discussion does not work effectively and the learning goals cannot be achieved. A more appropriate strategy needs to be implemented to solve those problems.

Harmer (2001:19) states that teaching reading is taught from elementary school to the college by using various strategies applied by English teacher. The strategy used should be a strategy that involves the students in the process of reading activity; therefore, the students will experience the learning and discover how to grasp the text. 
Besides reading comprehension strategies, another factor influencing the students' success in comprehending a reading text is a motivation. Researchers confirm that student's motivation is key factor in successful reading. Motivation boosts an individual's energy and activity level, motivation expresses an individual's image on certain goals, motivation promotes initiation of certain activities and persistence in those activities, motivation influences the learning strategies and cognitive processes an individual use (Elliot et. al, 2000:332). The effect of two factors which influencing reading comprehension (teaching reading comprehension strategies and motivation) was seen by conducting a research at the Eighth Grade of SMPN 2 Sawahlunto.

Gallery Walk strategy proposed by Francek (2006) was compared with Small Group Discussion by giving treatment to the students. In addition, the reading comprehension was a moderating variable since it has closed relation to Gallery walk.

The gallery walk is a cooperative learning strategy in which the instructor set up several questions/problems and posts each question/problem at a different table or at a different place on the walls (hence the name "gallery"). Students form as many groups as there are questions, and each group moves from question to question (hence the name "walk") (Silberman 2007:264).

Based on the definition above, Gallery walk is teaching strategy that not only assists students in activating the prior knowledge, but also encourages them to move around the classroom in order to accomplish the task, communicate with their friends, and discover the multiple texts.

In teaching reading comprehension using Gallery Walk the students will have their own role, they are Gallery Keeper and Visitor. The students first guess what the text will be about based on the pictures showed by the teacher, and after they formed in group, they are allowed to explore the classroom in order to seek the answer in galleries. Next, Students can back to their groups after all the members done visiting the gallery after that they compared their work in group. Finally, they are invited to compete in answering the question and respond to the other group answers.

There are some procedures in applying gallery walk strategy as Bowman (2005:5) suggests:

a. The teacher pins the paragraphs or images before the students entering the class.

b. The teacher taps out students to guess what activity that going to do.

c. The teacher illustrates how to use the gallery walk.

d. The teacher asks students to make 5 groups (consists of 4 students) and the students decide the role Gallery keeper: the person who stands in the gallery and serves the visitors. Gallery visitor: the person who visits the gallery and they can ask the gallery keeper to complete their work.

e. After getting their turn as gallery keeper, they have to move to other gallery as gallery visitor while waiting the chance as gallery keeper in their own gallery.

f. The teacher manages and identifies the students' problem in becoming the gallery keeper.

g. The teacher and the students discuss their works and problems in doing the gallery walk. 
Based on the procedures above, it can be concluded that, the teachers can modify the teaching procedures of gallery walk based on the skills which to be assessed.

Furthermore, motivation of reading is attempt of someone to achieve what they his/her really want to. This is supported by Harmer (2004: 51) defines motivation as some kind of internal drive which pushes someone to do things in order to achieve something.

In addition, Guthrie et al. (2006:284) says that interest in reading is a motivational construct that has been expressed as a personal investment. It means that, the students who have reading motivation, of course have interest first. Moreover, Jamestown (2006:7) states that reading motivation is an effort to generate certain circumstance in order someone want and willing to read and achieve the meaning from the text. The wanted circumstance will also lead in an interesting one which makes significance.

There are some aspects in enhancing student's motivation in reading. The first is the interesting text, according to Harris (1990:1) reading motivation can be enhanced in two ways: first, by employing material which is intrinsically able to magnetize and hold the reader' attention. The other is by using the materials that are available in ways which promote curiosity. It can be summarized that, suitable material and media to build students motivation is better considered in teaching reading.

Second, the teacher aspect, the teacher is a facilitator in boosting student's reading motivation. According to Gambrell, et al (2007:27), teacher need to bear students in their reading development by creating enthusiastic classrooms that promote reading motivation, such as providing a book with rich environment, opportunities for choice, and opportunities for interaction socially with others.

Naiman, et al, in Ur (1996: 275) state most of successful learners those who have characteristics as follow positive task orientation, Ego-involvement, need for achievement, high aspiration, goal orientation, perseverance, tolerance of ambiguity.

There are a lot of characteristics of motivated students, it can be summarized that motivation in learning is a theoretical construct used to enlighten the initiation, direction, intensity, and persistence of behavior with some characteristics of the students. Motivation is also a power of transform (inside or outside) within the person to do something for the sake of certain goal.

Furthermore, the definition of reading comprehension has been affirmed by experts in recent decades. The reading comprehension once develop is the one which can be most easily maintained at a high level by the students themselves without further aid from a teacher, through it they can boost their knowledge an understanding of the culture of the speakers of the language, their ways of thinking, their contemporary activities, and their contributions to many fields of artistic and intellectual endeavor.

Moreover, Schramm (2008:231) states that reading comprehension is an active process to construct the meaning and the understanding about the text. To do this there are two ways readers should do. First, a good reader will quickly reject the irrelevant information and find what he/she is searching for. Second, it is enough to understand the gist of the text only, but more detailed comprehension is necessary. 
In addition, Sheng (2000:13) says that comprehension is a process of negotiating understanding between the reader and the writer. It is more complex psychological process and includes linguistic factors like phonological, morphological, syntactic, and semantic elements. It means that comprehension is an interpretation what the readers think when they are reading. Furthermore, Nunan (2003: 68) states reading comprehension is a smooth process of readers combining information from a text and their background knowledge to build meaning and has comprehension as the goal.

It can be summarized that comprehension is very important while reading. The reader is not only read but also, he/she has to use the strategies to get the main point of the writer wants to tell in the text. The readers need engage their prior knowledge to understand the written text in context. And the prior knowledge itself will active automatically when the reader read the written text, it can make the reader easy to get the writer's intention.

Furthermore, reading is not only about activating prior knowledge but also it deals with mental such as curiosity, skills, attitudes and motivation. A good reader can relate whatever new information they encounter in texts to what they have already known to their cognitive structure. The readers' background knowledge integrates with the text to create meaning. Those theories provide the significance of reading comprehension including the strategies which are needed by the reader.

\section{METHODOLOGY}

This research was conducted by using quasi experimental research design with used $2 \times 2$ designs. This design was applied in order to examine the effect of Gallery walk and motivation toward students' reading comprehension.

The population of this research was the Eighth Grade Students of SMPN 2 Sawahlunto. There were eight classes, and the total number was 175 students. The sample was taken by using cluster random sampling. From the eight classes of SMPN 2 Sawahlunto, two classes were chosen randomly as the sample after the researcher got the normality and homogeneity of population. The sample was 42 students from two classes.

This research was conducted in 8 meeting for both experiment and control class. The instruments which used in this research were questionnaire and reading comprehension test. In order to ensure both instruments were valid, reliable and proper, the researcher validated them to the expert of Psychology for questionnaire and the researcher validated the reading test to the English teacher from SMPN 2 Sawahlunto.

After validating the instruments and tried them out, the questionnaire of motivation was distributed in the last meeting to gauge students' motivation in reading, reading comprehension test was distributed after.

The data from posttest was normal and homogeny as consequently the researcher analyzed the the score of students' motivation questionnaire and reading test by using parametric statistic; T-Test and Two Ways ANOVA.

The data of students' motivation were ranked from highest to the lowest score; $27 \%$ upper group students were grouped as students with high motivation while $27 \%$ lower grouped as students with low motivation. The classification was 
based on suggestion from Sudijono (2011:233) 27\% x 21 is 7 students. It can be summarized that 7 students with high motivation (experimental and control class) and 7 students with low motivation (experimental and control class).

\section{RESULT AND DISCUSSION}

The result of hypothesis 1 to 4 can be seen in the following table below:

\begin{tabular}{|c|c|c|c|c|}
\hline HYPOTHESIS & CLASS & MEAN & $t_{. o b}$ & $t_{\cdot t a b}$ \\
\hline \multirow[t]{2}{*}{1} & $\operatorname{Exp}$ & 81.43 & \multirow[b]{2}{*}{3.035} & \multirow[b]{2}{*}{1.684} \\
\hline & Control & 73.57 & & \\
\hline \multirow[t]{2}{*}{2} & Exp & 86.43 & \multirow[b]{2}{*}{2.310} & \multirow[b]{2}{*}{1.770} \\
\hline & Control & 77.14 & & \\
\hline \multirow[t]{2}{*}{3} & Exp & 77.14 & \multirow[b]{2}{*}{1.644} & \multirow[b]{2}{*}{1.770} \\
\hline & Control & 70.00 & & \\
\hline HYPOTHESIS & C.Alpha & Sig & \multicolumn{2}{|c|}{ Interpretation } \\
\hline 4 & 0.05 & 0.720 & \multicolumn{2}{|c|}{ No Interaction } \\
\hline
\end{tabular}

Based on the table above, it can be seen that gallery walk strategy significantly has better result on students' reading comprehension. The results are discussed below.

\section{The Students who were taught by using Gallery walk strategy have better result than students who were taught by using Small group discussion in reading comprehension text of narrative text.}

Based on the result, the mean score of experimental class which was taught by gallery walk strategy (81.43) was higher than control class which taught by small group discussion (73.57). Furthermore, the value of $t_{\text {observed }}$ is 3.035 and the value of $t_{\text {table }}$ is 1.682 , where if $t_{\text {observed }}$ is bigger than $t_{\text {table }}$ thus $H_{0}$ is rejected and $\mathrm{H}_{1}$ is accepted. It can be concluded that gallery walk strategy can enhance the students reading comprehension of narrative text.

Moreover, Gallery walk gave significant effect toward students' reading comprehension. This result was in line with the previous research finding which was conducted by Majiasih (2012). She concluded that there is a significant progress of applying Gallery walk Strategy on students' speaking skill than guided speaking. The similarities of this research with Majiasih (2012) was the strategy (gallery walk) while the differences were the dependent variable reading comprehension and speaking skill.

In addition, Gallery walk strategy gave more chance for the students to work together with the team, boosts the students' motivation, explore the multiple texts and move around the classroom to visit the galleries in order to accomplish the task. It is in line with Francek (2006) that states teachers often use this strategy as an option to have students express and share their work with peer, examine multiple texts and documents, or respond to a collection of quotations. Since this 
strategy entails students to physically move around the classroom, it can be especially engaging to kinesthetic students. It can be concluded that students who were taught by gallery walk had better reading comprehension of narrative text than those who were taught by using Small group discussion.

\section{The students who have high motivation were taught by using Gallery Walk strategy have better result than students who were taught by using Small Group Discussion in reading comprehension text of narrative text.}

Related to the result of hypothesis two, it shows that the students with high motivation who were taught by Gallery Walk strategy had higher score than the students with high reading motivation who were taught by Small group discussion. The mean score of experimental class was 86.43 while the control class was 77.14. Furthermore, the value of $t_{\text {observed }}$ is 2.310 and the value of $t_{\text {table }}$ is 1.770 , where if $t_{\text {observed }}$ is bigger than $t_{\text {table }}$ as a consequence $H_{0}$ is rejected and $\mathrm{H}_{1}$ is accepted. It can be concluded that gallery walk strategy work effectively with the students who have high motivation.

The students with high motivation prompts to have curiosity and know more about text they are reading. It happened since there is also class discussion. In class discussion, the students have to stand up in front of the class to share their ideas. It can be concluded that the students with high reading motivation who were taught by gallery walk strategy have better reading result than those who were taught by small group discussion.

There are some factors which involve in experimental class, the students have more opportunities to comprehend the text well and the students' activeness, since there are chances for them to discuss in group. After having discussion, they have to present the results and compete with the other groups, they are also allowed other students give comments whether it was correct or not. It is in line with Brophy (1998:3) which states motivation as the students' subjective experiences, especially their willingness to engage in lesson and learning activities and their reason for doing so.

It was different from the control class, where the students tended to be passive because only the active students which talk a lot and arguing. The passive students tended to wait for the teachers help when they bump into troubles.

It can be summarized that motivation is huge aspiration from inside which can drive person to pursue his/her goals.

\section{The students who have low motivation who were taught by using Gallery walk strategy does not achieve better result than the students who are taught by using small group discussion in reading comprehension of narrative text.}

Based on the result of hypothesis 3, the students with low reading motivation who were taught by Gallery walk do not get better result than the students with low motivation who taught by Small group discussion. It was proven by the mean score in experimental class 77.14 and control class was 70.00 . Besides, the value of $t_{\text {observed }}$ is 1.644 and the value of $t_{\text {.table }}$ is 1.770 , where if $t_{\text {observed }}$ is smaller than $t_{\text {table }}$ as a consequence $H_{0}$ is accepted and $H_{1}$ is rejected. 
It can be concluded that gallery walk strategy does not work effectively with the students who have low motivation.

The students' low motivation in control class did not know what to do in finding the information of the text or answering the other groups' question as a result they tended to be passive and unmotivated.

But the students with low motivation in experimental class did not involve actively to the activity and material given, they can get higher score than control class because some factors. First, the students enjoy the class because they can move around the classroom and communicate with the others. Second, they did not answer the questions by themselves only, but also they have to share which items that he/she want to handle. Last, the students were interested when they had competition. It is in line with Maslow (1970:32) which states motivation is the energy which supports learners in reaching their needs.

\section{There was no interaction between motivation and students' reading comprehension of narrative text.}

The fourth hypothesis of this research shows that the result of Significance value 0.720 was higher than Significance level 0.05. It means that Ho was accepted or there was no interaction of students' motivation on students' reading comprehension text of narrative text. Based on the chart of interaction, the significant interaction both of strategies used and reading motivation could be seen from the interactive graph, students' who were taught gallery walk strategy had higher mean score than the mean score of students' who were taught small group discussion. The mean score of students reading comprehension that have high and low reading motivation experimental class were higher than the mean score of reading comprehension that have high and low reading motivation in control class. Moreover, the differences of mean score both of experimental class and control that has high and low reading motivation at chart shows that the line was not parallel.

Based on the explanation above, there was no interaction between strategy and motivation on students' reading comprehension in narrative text. Based on the data statistic, Gallery walk strategy which used in experimental class is more effective than small group discussion. It means that Gallery walk strategy can be applied by any teachers and any classes, since it is appropriate with the level of the students. As a consequently, the students can expand their reading comprehension well and motivated to learn.

\section{CONCLUSION}

Based on the results of data analysis and the research findings that were conducted to the eighth-grade students of SMPN 2 Sawahlunto, several conclusions can be drawn. First, the Students who are taught by using Gallery walk strategy have better result than the students who are taught by using Small Group Discussion in reading comprehension of narrative text.

Second, the Students who have high motivation who are taught by using Gallery Walk have better result than the students who are taught by using Small group discussion in reading comprehension of narrative text. 
Third, the Students who have low motivation who are taught by using Gallery walk do not give better result than the students who are taught by using Small group discussion in reading comprehension of narrative text.

Last, there is no interaction between strategies and reading motivation on students 'reading comprehension of narrative text. It means that motivation (high and low) does not influence the result of students' reading comprehension.

\section{SUGGESTION}

It is needed to have further investigation as follow up the research that has been executed. The effect of further study will highlight the findings. Some suggestions for the teachers, learners and further researchers are describe below.

First, English teachers are encouraged to be more creative in deciding a variety of strategies that will be applied in teaching reading. It is aimed to magnetize the students' enthusiastic, enhance students' psychologically and physically in learning process. The teachers can browse multiple of teaching strategies in order to gain the core of teaching and to boost their teaching skill. Gallery walk is one of the teaching strategies that are effective to advance the students' reading comprehension. Additionally, teachers are also encouraged to pay an extra awareness in finding the solutions of the students' who have low achievement and motivation. The teacher can motivate them by using attractive activities which can boost their motivation in learning English especially in reading.

Furthermore, the students are encouraged to enhance their motivation and skill in learning process by getting involved actively in any activities in the classroom. As consequently, they will be able to gain better result in English particularly reading comprehension.

Last, the further researchers can be possible to investigate the gallery walk with some modification and revision or students' condition such as students' interest, self-esteem, self-confident, students' autonomy, students' learning style, personality etc.

\section{REFERENCES}

Bowman, Sharon. L. The Gallery Walk: An Opening, Closing, and Review Activity. Retrieved at http://www.Bowperson.com

Brophy, Jere. Motivating Students to Learn Second Edition. Lawrence Erlbaum Associates, publishers 2004 Mahwah, New Jersey London

http://www2.milwaukee.k12.wi.us/zablocki/MSTL.pdf

Elliot, A., Faler, J., McGregor, H., Campbell, W., Sedekid es, C., \& Harackiewicz, J. (2000). Competence valuation as a strategic intrinsic motivation process. Personality and Social Psychology Bulletin, 26, 780794

Francek, Mark. Promoting Discussion in the Science Classroom Using Gallery Walk: A Journal of College Science Teaching http://blog.stetson.edu/jrseminars/wp-content/uploads/Gallerywalk.pdf retrieved on 14th April 2014 
Gambrell, L.B Palmer, B.M.Codling, RM \& Mazzoni , S.A.(2007) Assessing Motivation to read. The reading teacher teacher, 49(7), 518, -522.

Guthrie, T., Laurel, W., Stephen, M., Nicole, M., L. 2006. Reading Motivation and Reading Comprehension Growth in the later elementary years. Maryland: University of Maryland College Park.

Harmer, J. 2001. The Practice of English Language Teaching Third Edition. Cambridge: Longman Company

Harris, A.J. 1990. How to Increase reading ability: A guide to development and remedial methods. New York :David Mckey

Jamestown. 2006. Motivation and Engagement: Interactive Educational System. New York:Mcgraw-Hill

Maslow, Abraham H. 1970. Motivation and Personality. Printed from the English edition by Harper and Row. Publisher 1954

Mccororie P. 2006. Teaching and Leading Small group. Edinburgh: Association for the study of Medical Science.

Nunan, David. 2003. Second Language Teaching and Learning. Heinle Publisher: Botton.

Schramm, Karen. 2008. Reading and Good Language Learners. In Carrol Griffiths (eds), Lesson from Language Learners: Cambridge: Cambridge University Press

Sheng, He Ji. 2000. “A Cognitive Model for teaching Reading Comprehension”. English Teaching Forum Vol. XXV, 4: 12-13

Silberman, Melvin L. 2007. Active Learning: 101 Strategi Pembelajaran Aktif. Dialihbahasakan oleh Sarjuli dkk. Yogyakarta: Pustaka Insan Madani.

Sudijono, A. 2011. Pengantar Evaluasi Pendidikan. JKT: PT. Raja Grafindo Persada

Taylor, P. 2001. Gallery Walk. Retrieved on 15 July 2015 at http://www.cct.umb.edu/gallerywalk.html

Ur, Penny. 1996. Discussion that Word: Language Book for Language teacher. London: Longman group Limited.

Ur, Penny. 2000. A Course in Language Teaching: Practice and Theory. Cambridge: Cambridge University Press 